\title{
Volatile Constituents, Antioxidant and Insecticidal Activities of Essential Oil from the Leaves of Thaumatococcus Danielli (Benn.) Benth. From Nigeria
}

\author{
Anthony B. Ojekale ${ }^{1 *}$, Oladipupo A. Lawal ${ }^{2}$, Adeola A. Segun ${ }^{1}$, Folorunso O. \\ Samuel $^{1}$, Azeez I. Ismaila ${ }^{1}$, and Andy R. Opoku ${ }^{3}$ \\ ${ }^{1}$ Department of Biochemistry, ${ }^{2}$ Department of Chemistry, Lagos State University, PMB 001, LASU Post Office, \\ Ojo, Lagos, Nigeria , ${ }^{3}$ Department of Biochemistry and Microbiology, University of Zululand, KwaDlangezwa
} 3886, South Africa

\begin{abstract}
The volatile constituents from the leaf oil of Thaumatococcus danielli (Benn.) Benth. growing in Nigeria was studied by GC and GC-MS. Twenty-one constituents were characterized representing $95.8 \%$ of the total oil. The major components of the oil were octadecamethyl cyclononasiloxane (48.3\%), phytol (12.9\%) and 6,10,14-trimethyl-2-pentadecanone (9.3\%). The antioxidant activity of the oil $(10-50 \mathrm{mg} / \mathrm{mL})$ was evaluated by measurement of 1,1-diphenylpicryl-hydrazyl (DPPH) radical, metal chelating and nitric oxide radical methods. The essential oil showed no metal chelating activity, but, displayed significant antioxidant activity against 1,1diphenyl-2-picrylhydrazyl (DPPH) and nitric oxide radicals with $I C_{50}$ values of 16.32 and $24.68 \mathrm{mg} / \mathrm{mL}$, respectively, compared to synthetic antioxidants: butylated hydroxyanisole, butylated hydroxytoluene, ascorbic acid and $\alpha$-tocopherol with $\left(I C_{50} \leq 17.96 \mathrm{mg} / \mathrm{mL}\right)$. The insecticidal activity was assayed against Sitophilus zeamais and the result showed $L C_{50}$ value of $345.2 \mathrm{mg} / \mathrm{mL}$ after $72 \mathrm{H}$.
\end{abstract}

Keywords: Thaumatococcus danielli, Marantaceae, essential oil, antioxidant, insecticidal,.

\section{INTRODUCTION}

Thaumatococcus danielli (Benn.) Benth. (syn: Phrynium daniellii) is a multipurpose rhizomatous, perennial and monocotyledonous plant propagated by itself through the rhizomes ${ }^{1}$. It belongs to the family Marantaceae and native to West Africa, particularly Ghana, Cote d'Ivoire and Nigeria. It also exist in the Princes Islands, Angola, the Central African Republic, Uganda and Indonesia ${ }^{2}$. The leaves $(\mathrm{ca} 45 \mathrm{~cm} \mathrm{x} 30 \mathrm{~cm}$ ) are ovate-elliptic rounded, truncate at the base and shortly acuminate at the apex, and of different sizes depending on maturity of the plant ${ }^{3-4}$. The inflorescences are simple with spikes and bracts of about $(8 \mathrm{to} 10 \mathrm{~cm})$ wide and (3 to $4 \mathrm{~cm}$ ) long, respectively. The flowers most prolific from July until late October, and ripening from January until mid-April are purple pinkish with short spikes and long bracts at the base of the swollen petiole $^{1}$. The fruit furnishes the protein sweetener which is widely used in beverage, confectionary and pharmaceuticals industries. In addition, the stalks in some cases are used to line utensils in which food is prepared particularly in Southwestern, Nigeria ${ }^{5}$. Furthermore, T. danielli has contributed to the rural economy of some West African natives, who have been using the various part of the plant for centuries in wrapping food materials, making thatching roots, weaving baskets, mats and as taste modifier ${ }^{5}$.

A survey of literature on $T$. danielli shows numerous investigations and the presence of alkaloids, flavonoids, tannins, saponins, anthraquinones and cardiac glycosides ${ }^{3-4}$. In addition, mineral composition, biological and chemical evaluations of $T$. danielli waste, and as well as, antimicrobial, autolytic and proteolytic activities $^{6-9}$. Previous phytochemical analyses of $T$. daniellii led to the isolation of carbohydrates, trypsin inhibitors, proteases, thaumatins I and $\mathrm{II}^{10}$.

In Southwest Nigeria, $T$. daniellii have been reported used in traditional primary health care delivery ${ }^{11-}$ 12 and also, a common feature at homes and parties, where the leaves are used in packaging and presentation of a variety of food items ${ }^{13}$. Although, the essential oil from the leaves of this plant was proposed as the source of flavor associated with foods wrapped in them ${ }^{4}$. However, to the best of our knowledge, no previous information concerning the chemical composition of essential oil of $T$. daniellii from Nigeria has been reported and no previous information on the constituents from the essential oil of $T$. daniellii is reported anywhere. In continuation of our studies, on the chemical composition and biological activity of the essential oils from aromatic and medicinal plants of Nigeria origin ${ }^{14-16}$, the present investigation reports for the first time the 
volatile constituents, antioxidant and insecticidal activities of essential oil from the leaves of T. daniellii growing wild in Lusada town, Ogun State, Southwestern part of Nigeria.

\subsection{Chemicals}

\section{MATERIALS AND METHODS}

Folin-Ciocalteau reagent, 2,2-Diphenyl-1-picryl-hydrazyl (DPPH), 4,4- [3-(2-pyridinyl)-1,2,4-triazine-5,6-dryl] bisbenzene sulphonic acid (ferrozine), naphthylethylenediamine dihydrochloride, sodium nitroprusside, sulphanilic acid, butylated hydroxyanisole (BHA), butylated hydroxytoluene (BHT), gallic acid, ascorbic acid (AA), $\alpha$-tocopherol and Dimethylsulfoxide (DMSO) were obtained from Sigma-Aldrich Co., Ltd (Steinheim, Germany). All other chemicals and solvents were of analytical grade.

\subsection{Plant Material}

Fresh leaves materials of $T$. daniellii were collected from Lusada town, Ado-Odo/Ota Local Government Area, Ogun State, Nigeria. Identification of the plant material was done at the Department of Botany, University of Lagos, Akoka-Yaba, Lagos, by Mr. T. K Odewo. A voucher specimen (LUH 5246) was deposited in the Herbarium of the University.

\subsection{Isolation of essential oils}

Air-dry and crushed leaves $(250 \mathrm{~g})$ of $T$. daniellii were subjected to hydrodistillation using Clevengertype apparatus for $8 \mathrm{~h}$ in accordance with the British Pharmacopoeia specification ${ }^{17}$. The distillate isolated was preserved in a sealed sample tube and stored under refrigeration until analysis.

\subsection{GC analyses}

GC analysis was carried out on a Hewlett Packard HP 6820 Gas Chromatograph equipped with a FID detector and HP-5MS column ( $60 \mathrm{~m} \times 0.25 \mathrm{~mm}$ id), film thickness was $0.25 \mu \mathrm{m}$ and the split ratio was $1: 25$. The oven temperature was programmed from $50{ }^{\circ} \mathrm{C}$ (after $2 \mathrm{~min}$ ) to $240{ }^{\circ} \mathrm{C}$ at $5{ }^{\circ} \mathrm{C} / \mathrm{min}$ and the final temperature was held for $10 \mathrm{~min}$. Injection and detector temperatures were $200{ }^{\circ} \mathrm{C}$ and $240{ }^{\circ} \mathrm{C}$, respectively. Hydrogen was the carrier gas. An aliquot $(0.5 \mu \mathrm{L}$ of the diluted oil) was injected into the GC. Peaks were measured by electronic integration. A homologous series of $n$-alkanes were run under the same conditions for determination of retention indices.

\subsection{GC-MS analyses}

GC-MS analysis of the oil was performed on a Hewlett Packard Gas Chromatography HP 6890 interfaced with a Hewlett Packard 5973 mass spectrometer system equipped with a HP-5MS capillary column $(30 \mathrm{~m} \times 0.25 \mathrm{~mm}$ id, film thickness $0.25 \mu \mathrm{m})$. The oven temperature was programmed from $70-240^{\circ} \mathrm{C}$ at the rate of $5^{\circ} \mathrm{C} / \mathrm{min}$. The ion source was set at $240^{\circ} \mathrm{C}$ and electron ionization at $70 \mathrm{eV}$. Helium was used as the carrier gas at a flow rate of $1 \mathrm{~mL} / \mathrm{min}$. The scanning range was 35 to $425 \mathrm{amu}$. Diluted oil in $n$-hexane $(1.0 \mu \mathrm{L})$ was injected into the GC/MS.

\subsection{Identification of compounds}

The components of the oil were identified base on the comparison of their retention indices and mass spectra with those standards, Wiley library mass spectra database of the GC/MS system and published data ${ }^{18-20}$.

\subsection{Antioxidant activity}

\subsubsection{1,1-diphenylpicryl-hydrazyl radical scavenging activity}

The free radical scavenging ability of the essential oils was evaluated as described ${ }^{21}$ and modified ${ }^{22}$. $0.2 \mathrm{~mL}$ of different concentrations $(10-250 \mu \mathrm{g} / \mathrm{mL})$ of $T$. daniellii essential oils in methanol was mixed with $2.7 \mathrm{~mL}$ of $1.0 \times 10^{-4} \mathrm{M}$ methanol solution of DPPH. The absorbance at $517 \mathrm{~nm}$ was measured using UV-Visible Genesys 20 spectrophotometer; after the solution had been allowed to stand in the dark for $60 \mathrm{~min}$. The absorbance of the samples, the control and the blank were measured in comparison with methanol. Lower absorbance of the reaction mixture indicates higher DPPH scavenging activity. BHT, BHA, ascorbic acid and $\alpha-$ tocopherol were used as standards.

DPPH scavenging activity was calculated using the following formula: DPPH scavenging activity $(\%)=\{1-(\mathrm{S}-\mathrm{SB}) /(\mathrm{C}-\mathrm{CB})\} \times 100 \%$

Where S, SB, C and CB were the absorbances of the sample, the blank sample $(2.0 \mathrm{~mL}$ of methanol plus $0.2 \mathrm{~mL}$ of sample at different concentrations), the control ( $2.0 \mathrm{~mL}$ of DPPH solution plus $0.2 \mathrm{~mL}$ of methanol), and the blank control (methanol) respectively. The concentration providing $50 \%$ inhibition $\left(\mathrm{IC}_{50}\right)$ was calculated from the graph of percentage inhibition against oil concentrations. 


\subsubsection{Metal chelating activity}

The $\mathrm{Fe}^{2+}$ chelating effect of the oil was measured ${ }^{23}$. To $0.5 \mathrm{~mL}$ of various concentrations $(0-50 \mathrm{mg} / \mathrm{L})$ of T. daniellii essential oil in methanol, $1.6 \mathrm{~mL}$ of deionized water and $0.05 \mathrm{~mL}$ of $\mathrm{FeCl}_{2}(2 \mathrm{mM})$ were added. After $30 \mathrm{~s}$, the reaction was initiated by the addition of $5 \mathrm{Mm}$ ferrozine $(0.1 \mathrm{~mL})$. Then, the mixture was shaken and left at room temperature for $10 \mathrm{~min}$. Absorbance of the mixture was measured spectrophotometrically at 562 $\mathrm{nm}$. Ascorbic acid and $\alpha$-tocopherol were used as standard.

The inhibitory effect of $T$. daniellii essential oil was calculated as:

$$
\% \text { Inhibition }=\left\{\left(\mathrm{A}_{0}-\mathrm{A}_{1}\right) / \mathrm{A}_{0} \times 100\right\}
$$

Where, $A_{0}$ is the absorbance value of the fully oxidized control and $A_{1}$ is the absorbance of the oil. The inhibitory concentration providing $50 \%$ inhibition $\left(\mathrm{IC}_{50}\right)$ was calculated from the graph of percentage inhibition against $T$. daniellii essential oil concentrations.

\subsubsection{Nitric Oxide Radical (NO·) scavenging activity}

The scavenger activity of $T$. daniellii essential oil to competes with oxygen and reduces the production nitric oxide was determined using Griess Illosvoy reaction Garrat ${ }^{24}$. The reaction mixture $(3 \mathrm{~mL})$ containing 2 $\mathrm{mL}$ of $10 \mathrm{mM}$ sodium nitroprusside, $0.5 \mathrm{~mL}$ of phosphate buffer saline $(\mathrm{pH} 7.4,0.01 \mathrm{M})$ and $0.5 \mathrm{~mL}$ of different concentrations of essential oil were incubated at $25^{\circ} \mathrm{C}$ for $150 \mathrm{~min}$. Thereafter, $0.5 \mathrm{~mL}$ of the reaction mixture containing nitrite was pipette and mixed with $1 \mathrm{~mL}$ of sulphanilic acid reagent $(0.33 \%$ in $20 \%$ glacial acetic acid) and allowed to stand for $5 \mathrm{~min}$ for completing diazotisation. Then, $1 \mathrm{~mL}$ of naphthylethylenediamine dihydrochloride $(0.1 \%)$ was added, and allowed to stand for $30 \mathrm{~min}$ in diffused light. The absorbance of the pink coloured chromophore was measured at $540 \mathrm{~nm}$ against the corresponding blank solution. BHT, BHA, ascorbic acid and $\alpha$-tocopherol were used as standards.

The inhibitory effect of $T$. daniellii essential oil was calculated by:

$$
\% \text { Inhibition }=\left\{\left(\mathrm{A}_{0}-\mathrm{A}_{1}\right) / \mathrm{A}_{0} \times 100\right\}
$$

Where $A_{0}$ is the absorbance of the control and $A_{1}$ is the absorbance in the presence of the essential oils. The concentration providing 50\% inhibition $\left(\mathrm{IC}_{50}\right)$ was calculated from the graph of percentage inhibition against oil concentrations.

\subsection{Insecticidal activity}

The fumigant toxicity of $T$. daniellii essential oil was assayed ${ }^{25}$. Adult insects of mixed sex, 7-14 days old of Sitophilus zeamais reared on maize and at $25 \pm 1{ }^{\circ} \mathrm{C}$ and $65 \% \pm 5 \%$ relative humidity (R.H.) was used for the bioassay. Filter paper (Whatman No. 1, cut into 2 -cm diameter pieces) was impregnated with $T$. daniellii oil at doses calculated to give equivalent fumigant concentrations of 5, 10, 20, 50, 100 and $250 \mathrm{mg} / \mathrm{L}$ air. The impregnated filter paper was then attached to the undersurface of the Petri dishes $(90 \mathrm{~mm})$ containing 10 adults each of A. obtectus, S. zeamais and T. castaneum to different concentrations of the oil. Each concentration and the control were replicated three times. Mortality was determined after 24, 48 and $72 \mathrm{~h}$ from the commencement of exposure. When no leg movement was observed, insects were considered dead. The percentage insect mortality was calculated using Abbott's formula for natural mortality in untreated controls ${ }^{26}$. Probit analysis was used to estimate $\mathrm{LC}_{50}$ value.

\subsection{Statistics}

The mean and standard deviation of three experiments were determined. Statistical analysis of the differences between mean values obtained for experimental groups were calculated as means \pm standard deviation (SD) of three independent measurement using Microsoft excel program, 2003 and Origin 6.0 for $\mathrm{IC}_{50}$. Data were subjected to one way analysis of variance (ANOVA). $P$ values $\leq 0.05$ were regarded as significant and $P$ values $\leq 0.01$ as very significant.

\section{RESULTS}

Table I: Volatile constituents of essential oil of Thaumatococcus danielli ${ }^{\mathrm{a}}$

\begin{tabular}{|c|c|c|c|c|}
\hline Compound & MF & Mw & RT & \% Area \\
\hline 3,7-dimethylnonane & $\mathrm{C}_{11} \mathrm{H}_{24}$ & 156.4 & 3.95 & 1.1 \\
\hline 3,6-dimethyl undecane & $\mathrm{C}_{13} \mathrm{H}_{28}$ & 184.3 & 4.2 & 1.7 \\
\hline Dodecamethyl cyclohexasiloxane & $\mathrm{C}_{12} \mathrm{H}_{36} \mathrm{O}_{6} \mathrm{Si}_{6}$ & 444.9 & 4.59 & 0.8 \\
\hline 2,3,5-trimethyl decane & $\mathrm{C}_{13} \mathrm{H}_{28}$ & 184.3 & 5.96 & 1.3 \\
\hline Tetradecamethyl cycloheptasiloxane & $\mathrm{C}_{14} \mathrm{H}_{42} \mathrm{O}_{7} \mathrm{Si}_{7}$ & 519 & 7.38 & 0.6 \\
\hline Decamethyl cycloheptasiloxane & $\mathrm{C}_{10} \mathrm{H}_{30} \mathrm{O}_{5} \mathrm{Si}_{5}$ & 370 & 9.95 & 1.6 \\
\hline
\end{tabular}


Volatile Constituents, Antioxidant And Insecticidal...

\begin{tabular}{|c|c|c|c|c|}
\hline 6,10,14-trimethyl-2-pentadecanone & $\mathrm{C}_{18} \mathrm{H}_{36} \mathrm{O}$ & 268.4 & 13.04 & 9.3 \\
\hline Methyl pentadecyl ether & $\mathrm{C}_{16} \mathrm{H}_{34} \mathrm{O}$ & 242.4 & 13.22 & 1.1 \\
\hline 3,7,11-trimethyl-2,6,10-dodecatrien-1-ol & $\mathrm{C}_{15} \mathrm{H}_{26} \mathrm{O}$ & 222.3 & 14.3 & 4.5 \\
\hline n-Hexadecanoic acid & $\mathrm{C}_{16} \mathrm{H}_{32} \mathrm{O}$ & 256.4 & 15.61 & 2.8 \\
\hline (E)-3-Eicosene & $\mathrm{C}_{20} \mathrm{H}_{40}$ & 280.5 & 16.1 & 3.1 \\
\hline Phytol & $\mathrm{C}_{20} \mathrm{H}_{40} \mathrm{O}$ & 296.5 & 16.34 & 12.9 \\
\hline Geranylgeraniol & $\mathrm{C}_{20} \mathrm{H}_{34} \mathrm{O}$ & 290.4 & 16.88 & 2 \\
\hline Octadecamethyl cyclononasiloxane & $\mathrm{C}_{18} \mathrm{H}_{54} \mathrm{O}_{9} \mathrm{Si}_{9}$ & 667.3 & 21.49 & 43.8 \\
\hline Squalene & $\mathrm{C}_{30} \mathrm{H}_{50}$ & 410.7 & 23.02 & 0.6 \\
\hline Tetratetracontane & $\mathrm{C}_{44} \mathrm{H}_{90}$ & 619.1 & 23.31 & 0.8 \\
\hline Tetradecanal & $\mathrm{C}_{14} \mathrm{H}_{28} \mathrm{O}$ & 212.3 & 27.73 & 1.3 \\
\hline 13-Tetradecen-1-ol acetate & $\mathrm{C}_{16} \mathrm{H}_{30} \mathrm{O}_{2}$ & 254.4 & 28.58 & 1.9 \\
\hline Oleic acid & $\mathrm{C}_{18} \mathrm{H}_{34} \mathrm{O}_{2}$ & 282.4 & 29.37 & 0.1 \\
\hline 9-Hexadecenoic acid, octadecyl ester & $\mathrm{C}_{34} \mathrm{H}_{66} \mathrm{O}_{2}$ & 506.8 & 29.91 & 2.2 \\
\hline 2- Chloropropionic acid, hexadecyl ester & $\mathrm{C}_{19} \mathrm{H}_{37} \mathrm{ClO}_{2}$ & 332.9 & 30.78 & 2.3 \\
\hline Total identified & & & & 95.8 \\
\hline
\end{tabular}

${ }^{\text {a }}$ Compounds are listed in order of elution.

${ }^{\mathrm{b}} \mathrm{RI}=\mathrm{RI}$ (retention index) calculated from retention times relative to that of $n$-alkanes $\left(\mathrm{C}_{6}-\mathrm{C}_{24}\right)$ on the non-polar HP-5MS column.

Table II: Antioxidant and insecticidal activities of $T$. danielli essential oil ${ }^{a}$

\begin{tabular}{|l|l|l|l|}
\hline & \multicolumn{1}{|c|}{ Antioxidant activity ${ }^{\text {a }}$} & \multicolumn{2}{|l|}{ Insecticidal activity $\left(\mathbf{L C}_{\mathbf{5 0}}\right)$ @ } \\
\cline { 2 - 4 } & DPPH & Nitric oxide & 72 \\
\hline T. danielli b,c & 26.3 & 19.6 & 345.2 \\
\hline BHT $\left(\mathrm{IC}_{50}\right)$ & 35.9 & - & - \\
\hline BHA $\left(\mathrm{IC}_{50}\right)$ & 36.1 & - & - \\
\hline Ascorbic acid $\left(\mathrm{IC}_{50}\right)$ & 36.8 & 25.2 & - \\
\hline$\alpha$-Tocopherol $\left(\mathrm{IC}_{50}\right)$ & 41.7 & 37.9 & - \\
\hline Allethrin $\left(\mathrm{LC}_{50}\right)$ & - & - & 7.45 \\
Permethrin $\left(\mathrm{LC}_{50}\right)$ & - & - & 11.1 \\
\hline
\end{tabular}

${ }^{\mathrm{a}}\left(\mathrm{n}=3, \mathrm{X} \pm \mathrm{SEM} ;{ }^{\mathrm{b}}\left(\mathrm{IC}_{50}\right)\right.$ - value determined to be the inhibitory concentrations at which DPPH and nitric oxide radicals were scavenged by $50 \%$ respectively.

${ }^{\mathrm{c}} \mathrm{LC}_{50}$ - Lethal concentrations with $50 \%$ mortality.

\section{DISCUSSION}

Hydrodistillation of the leaves of $T$. daniellii gave $0.09 \%$ yield of pale yellow oil. Analysis of the oil shows the presence of 21 constituents, accounting for $95.8 \%$ of the total oil. Table I shows the volatile components of the oil sample, where compounds are listed in order of their elution from the DB-5 column. A classification of the constituents of the oil showed the presence of a wide range of compounds, including polysiloxanes, terpenoids, aromatics, long-chain hydrocarbons, polysteroids, alcohols, aldehydes, ketones, fatty acids and their esters. The polysiloxane compounds were predominant constituents, with octadecamethyl cyclononasiloxane $(48.3 \%)$ being most dominate. Other major constituents were phytol $(12.9 \%), 6,10,14-$ trimethyl-2-pentadecanone $(9.3 \%)$, 4-methyl-2-octadiene $(4.5 \%),($ E)-3-eicosene $(3.1 \%)$ and hexadecanoic acid $(2.8 \%)$. Interestingly, octadecamethyl cyclononasiloxane, which was found to be a major component in our study, has not been reported as the main constituent in any genus of the Marantaceae family. Though, it has been reported as a constituent of some plant extracts ${ }^{12,27}$.

The ability of $T$. daniellii essential oil to scavenge DPPH radical, metal chelating and nitric oxide radical scavenging activities was evaluated and the result is shown in Table II. The result shows that the $T$. daniellii essential oil, did not exhibit any activity for metal chelating, but, significantly and dose dependently reduced DPPH radicals. At a concentration of $50 \mathrm{mg} / \mathrm{L}, T$. daniellii essential oil scavenged over $80 \%$ of DPPH radicals with $\mathrm{IC}_{50}$ value of $26.3 \mathrm{mg} / \mathrm{L}$ which was greater than the synthetic antioxidant, BHA (36.1mg/L), BHT $(35.9 \mathrm{mg} / \mathrm{L})$, ascorbic acid $(36.8 \mathrm{mg} / \mathrm{L})$ and $\alpha$-tocopherol $(41.7 \mathrm{mg} / \mathrm{L})$, respectively. The oil was also found to be very effective scavenger of nitric oxide radical and the activity increased in a concentration dependent manner (Table 11). At $50 \mathrm{mg} / \mathrm{L}$, the oil exerted the highest nitric oxide scavenging activity of $78.5 \%$ ( $\mathrm{IC}_{50}$ of 19.6 $\mathrm{mg} / \mathrm{L}$ ), whereas ascorbic acid and $\alpha$-tocopherol exhibited lower activities. From the results, it can be observed that the essential oil of $T$. daniellii is a good free radical scavenger, and it could effectively act as a primary antioxidant against free radicals and can be regarded as a good source of natural antioxidant in preventing lipid peroxidation and protection from oxidative stress caused by excess nitric oxide radical generation such as inflammation, cancer and other physical or mental disorders that are harmful to human health ${ }^{28}$. The insecticidal 
activity of T. daniellii essential oil was determined against Sitophilus zeamais. Table II shows the result of the toxicity of $T$. daniellii essential oil and the control (permethrin and allethrin) after $72 \mathrm{~h}$ was found to be directly proportional to the different concentrations of the oil, with lethal concentration $\left(\mathrm{LC}_{50}\right)$ of $345.2 \mathrm{mg} / 100 \mathrm{ml}$, compared to the standard permethrin $\left(\mathrm{LC}_{50}=7.45\right.$ and $\left.11.13 \mathrm{mg} / 100 \mathrm{ml}\right)$. It is apparent that $T$. daniellii essential oil has a weak toxic activity. However, the findings of this study are in agreement with other previous reports on insecticidal activities of some essential oils against storage-product beetles ${ }^{29-30}$. Although, the effectiveness of octadecamethyl cyclononasiloxane as a constituent of essential oil has not yet been known. However, it is perceptible that the antioxidant activity and the relatively weak toxic effect of $T$. daniellii may have contributed to its uses in food and pharmaceuticals industries, as well as in traditional medicine of some West Africa countries.

\section{REFERENCES}

[1] Onwueme, I.C, Onochie B.E and Safowora E.A. (1979). Cultivation of T.daniellii-the sweetener, World Crops, p. 106.

[2] Arowosoge, O.G.E and Labode, (2006). Economic analysis of Thaumatococcus danielli (Benn.) benth. (Miraculous berry) in Ekiti State, Nigeria. Journal of Food Agriculture \& Environment. 4(1): 264-269.

[3] Grillo J.A. and Lawal A. K. (2010). In vitro activity of Thaumatococcus daniellii and Megaphrynium macrostachyum against spoilage fungi of white bread and 'Eba', an indigenous staple food in Southern Nigeria. African Journal of Microbiology Research. 4; 1076-1081

[4] Ojekale A. B., Makinde S. C. O and Osileye O. (2007). Phytochemistry and antimicrobial evaluation of Thaumatococcus danielli Benn. (Benth.) leaves. Nig. Food J. 25(2): 176-183.

[5] Amusa T. O. Jimoh S. O and Azeez I. O. (2012). Prevalence, Utilization and Conservation Strategies for Non-Timber Forest Products in South Western Zone of Nigeria. Resources and Environment. 2, 46-54

[6] Elemo, B.O., Adu, O.B. and Alabi, A.M. (2001). Isolation and partial purification of carbohydrate component of Thaumatococcus danielli (Benth.) Nig. J. Biochem. and Molecular Biol., 16: 87-90.

[7] Elemo, B.O., Adu, O.B. and Ikiabekhe, M.A. (1999). Studies on the mineral composition of Thaumatococcus danielli waste. Nig. Food J., 17: 52-54.

[8] Elemo, B.O., Adu, O.B., Ogunrinola, O.O., Efuwape, T.O., Olaleye, K. O. and Kareem A.A. (2011). Biological Evaluation of Thaumatococcus danielli Waste Protein. Pakistan Journal of Nutrition. 10; 1048-1052.

[9] Raimi, O. G., Elemo, B. O., Fatai, A. A., Bankole, H. A., Kazeem, M. I and Banjoko, A. O. (2011). Isolation and partial characterization of a protease enzyme from Thaumatococcus daniellii waste. African Journal of Biotechnology; 10; 3186-3190.

[10] Stephen A. G, Powls R and Beynon R. J. (1994). Cysteine protease activity in arils of Thaumatococcus daniellii: Relationship between the sweet protein thaumatin and cysteine protease activity. International Journal of Biochemistry. 26, 879-884.

[11] Kadri A, Zarai Z, Békir A, Gharsallah N, Damak M and Gdoura R. (2011). Chemical composition and antioxidant activity of Marrubium vulgare L. essential oil from Tunisia. African Journal of Biotechnology, 10(19), 3908-3914

[12] Olowokudejo, J. D.; Kadiri, A. B.; and Travih, V. A. (2008) "An Ethnobotanical Survey of Herbal Markets and Medicinal Plants in Lagos State of Nigeria," Ethnobotanical Leaflets: Vol. 2008: Iss. 1, Article 116

[13] Adegunloye D. V, Agarry O. O, Adebolu T. T and Adetuyi F. C. (2006). Effect of leaf-packaging on the microbiological assessment of some food items. African Journal of Biotechnology 5, 445-447.

[14] Kasali A. A, Lawal O. A, Eshilokun A. O, Olaniyan A. A, Opoku A. R and Setzer W. N. (2011). Citrus Essential Oil of Nigeria Part V: Volatile Constituents of Sweet Orange Leaf Oil (Citrus sinensis). Natural Product Communications, 6, 875-878.

[15] Owolabi M. S, Lawal O. A, Paudel P, Setzer W. N and Labunmi L. (2012). Assessment of essential oil composition and insecticidal activity of Aristolochia ringens from Nigeria. Biopesticides International, 8 (1), 26-31

[16] Omikorede, O.E., Lawal, O A and Iresemowo, O A. (2012). Volatile constituents, antibacterial and insecticidal activities of essential oil from the leaves of Vitex agnus-castus L. (Verbenaceae). Canadian Journal on Computing in Mathematics, Natural Sciences, Engineering and Medicine, 3 (7), 256-260.

[17] British Pharmacopoeia. (1988). Part II: HMSO, London. 109-110.

[18] Adams, R. P. (1989). Identification of Essential Oil Components by ion trap mass spectroscopy. Academic Press: New York. U.S.A.

[19] Joulain, D and Koenig. W.A. (1998). The atlas of spectral data of sesquiterpenes hydrocarbons. E.B-Verlag: Hamburg, Germany.

[20] ESO 2000. (1999). The complete database of essential oils. Boelens Aroma Chemical Information Service. The Netherlands.

[21] Pyo, Y.H, Lee, T.C, Logendrac, L and Rosen, R.T. (2004). Antioxidant activity and phenolic compounds of Swiss chard (Beta vulgaris subspecies cycla) extracts. Food chemistry, 85, 19-26.

[22] Han, J, Weng, X and Bi, K. (2008). Antioxidants from a Chinese medicinal herb - Lithospermum erythrorhizon. Food chemistry, $106,2-10$.

[23] Dinis, T.C.P., Madeira, V.M.C., Almeida, L.M., 1994. Action of phenolic derivatives (acetaminophen, salicylate, and 5aminosalicylate) as inhibitors of membrane lipid-peroxidation and as peroxyl radical scavengers. Archives of Biochemistry and Biophysics 315, 161-169.

[24] Badami, S, Rai, S.R and Suresh, B. (2005). Antioxidant activity of Aporosa lindleyana root. Journal of Ethnopharmacology, 101, 180-184.

[25] Hashemi S. M and Safavi S. A. (2012). Chemical constituents and toxicity of essential oils of Oriental arborvitae, Platycladus orientalis (1.) Franco, against three stored-product beetles Chilean Journal of Agricultural Research, 72: 88-194.

[26] Abbott W. S. (1925). A method for computing the effectiveness of an insecticide. Journal of Economic Entomology, 18: 265267.

[27] Sagwan S, Rao D.V and Sharma R.A. (2012). Studies on GC/MS spectroscopic analysis of some different in vivo plant extracts of (karanj) Pongamia pinnata (L.): Pierre. Journal of Global Pharma Technology. 8: 1-10

[28] Moure A, Cruz J.M, Fraco D, Dominguez J.M, Sineiro J, Dominguez H, Nunez M.J and Parajo J.C. (2001). Natural antioxidants from residual sources. Food Chem. 72: 145-171.

[29] Negabhan M, Moharramiour S and Sefidon F (2007). Fumigant toxicity of essential oil from Artemisia sieberi Besser against three stored product insects. Journal of Stored Products Research, 43: $123-128$

[30] Ayvaz A, Sagdic O, Karaborklu and Oztuk I. (2010). Insecticidal activity of the essential oils from different plants against three stored-product insects. Journal of Insect Science. 10: 21 